\title{
IDENTIFIKASI BORAKS PADA PENTOL BAKSO DI KELURAHAN AIR HITAM DENGAN PEREAKSI KULIT BUAH NAGA MERAH (Hylocereus polyhizus)
}

\author{
Dwi Lestari ${ }^{1}$, Muthia Dewi MA ${ }^{2}$, Suci Cahya Ningsih ${ }^{3,}$ Hidayati $^{3}$ \\ 1,2,3,4 Universitas Muhammadiyah Kalimantan Timur \\ Email korespondensi: $\underline{\text { d1792@umkt.ac.id }}$
}

\begin{abstract}
ABSTRAK
Boraks sering disalahgunakan untuk mengawetkan berbagai makanan seperti mie basah, bakso, lontong, ketupat dan sebagainya. Kulit buah naga merah mengandung metabolit sekunder yaitu antosianin, antosianin merupakan pewarna yang paling penting dan tersebar luas dalam kulit buah naga merah, tetapi pemanfaatan kulit buah naga merah belum banyak di teliti secara alamiah. Tujuan penelitian ini adalah untuk mengidentifikasi boraks pada pentol bakso yang dijual didaerah kelurahan Air Hitam dengan pereaksi kulit buah naga merah (Hylocereus polyhizus). Penelitian ini bersifat eksperimental dengan teknik pengambilan data secara Purposive Sampling. Pada penelitian ini digunakan beberapa sampel pentol bakso yang dibeli di pedagang bakso yang berada di Kelurahan Air Hitam dengan menggunakan kulit buah naga dan Pereaksi $\mathrm{AgNO}_{3}$ sebagai indikator pembanding. Penelitian ini meliputi determinasi tumbuhan, pengumpulan sampel, preparasi sampel, pembuatan spike, pembuatan pereaksi sari kulit buah naga serta pengujian sampel secara kualitatif. Analisis data dengan menggunakan metode analisis deskritif.Hasil identifikasi boraks pada 5 sampel pentol bakso dengan menggunakan pereaksi warna dari ekstrak (sari) kulit buah naga merah dan Pereaksi $\mathrm{AgNO}_{3}$ sebagai indikator pembanding menunjukkan bahwa seluruh sampel pentol bakso didapatkan hasil Negatif .
\end{abstract}

Kata kunci: Pentol bakso, boraks, pereaksi kulit buah naga 


\title{
IDENTIFICATION OF MEATBALLS AMALGAM OF BORAX IN VILLAGE WATER WITH BLACK LEATHER REAGENT RED DRAGON FRUIT (Hylocereus polyhizus)
}

\begin{abstract}
Borax is often misused to preserve various foods such as wet noodles, meatballs, rice cake, rhombus and so on. Red dragon fruit skin contains secondary metabolites, namely anthocyanin, anthocyanin is the most important and widespread dye in the skin of red dragon fruit, but the use of red dragon fruit peels has not been studied much naturally. The purpose of this study was to identify borax on the meatball sold in the Air Hitam district with the red dragon fruit skin reagent (Hylocereus polyhizus). This research is experimental with data collection techniques by accidental sampling. In this study used several samples of meatball pentol purchased at the meatball merchant located in Air Hitam Village by using dragon fruit peel and $\mathrm{AgNO}_{3}$ reagent as a comparison indicator. This research includes plant determination, sample collection, sample preparation, spike making, dragon fruit skin extract reagents and qualitative sample testing. Data analysis using descriptive analysis method. The results of the identification of borax on 5 meatball samples using color reagents from the extract (essence) of the red dragon fruit peel and AgNO3 reagent as a comparative indicator showed that all samples of the meatball obtained Negative results.
\end{abstract}

Keywords: Meatball, borax, dragon fruit skin reagents

\section{PENDAHULUAN}

Boraks termasuk zat pengawet yang berbahaya dan tidak diizinkan penggunaannya dalam makanan. Dalam industri kimia boraks sering digunakan untuk pembuatan logam, pengawet kayu dan pembasmi kecoa. Dalam industri makanan boraks sering ditambahkan pada produk bakso, tahu, mie, lontong atau ketupat, bahkan sayuran dalam pecel agar kelihatan lebih segar. Boraks dapat merusak sel-sel pada tubuh antara lain susunan saraf pusat, ginjal dan hati. Gejala yang sering dirasakan oleh orang yang mengkonsumsi makanan yang mengandung boraks adalah mual, muntah, diare, kram perut, iritasi kulit, dan kejang-kejang (Lestari et al., 2018) \& (Hartati, 2017).

Provinsi Kalimantan Timur menjadi salah satu pusat produksi buah naga di Indonesia. Pemanfaatan tanaman kulit buah naga selama ini hanya terbatas pada daging buahnya saja, sedangkan bagian lainnya terutama kulit buah naga belum banyak dimanfaatkan. Kulit buah naga merah memiliki pigmen zat warna alami yaitu Antosianin. Antosianin merupakan pewarna yang paling penting dan tersebar luas dalam tumbuhan. Pigmen yang berwarna kuat dan larut dalam air 
ini merupakan penyebab hampir semua warna merah jambu, merah marak, merah, ungu, dan biru antosianin bisa di kelompokkan dalam golongan flavanoid. Secara kimiawi ada beberapa faktor yang mempengaruhi kestabilan antosianin, salah satunya adalah protein. Apabila sumber antosianin bereaksi dengan protein maka akan menyebabkan perubahan warna, pembentuk endapan atau uap (Khaira, 2016) \& (Syamsul et al., 2018).

Untuk mengidentifikasi boraks pada makanan dapat menggunakan metode nyala api dan metode curcuma tetapi pengujian tersebut harus dilakukan di Laboratorium menggunakan larutan kimia (Indrati dan Gardijo, 2013). Peneliti tertarik menggunakan pereaksi kulit buah naga merah sebagai pereaksi untuk mengidentifikasi boraks. Kulit buah naga merah memiliki kandungan zat aktif seperti antosianin, karena antosianin akan mudah bereaksi jika dicampur dengan asam kuat yang dapat merubah warnanya semakin pekat jika bereaksi dengan asam, selain itu cara tersebut dapat dilakukan oleh masyarakat dengan mudah untuk mengetahui ada atau tidaknya bahan pengawet dalam makanan pentol bakso dengan menggunakan bahan alami salah satunya kulit buah naga.

Mengidentifikasi boraks pada pentol bakso yang di jual dipedagang bakso yang berada di Kelurahan Air Hitam dengan menggunakan kulit buah naga. Penelitian ini meliputi determinasi tumbuhan, pengumpulan sampel, preparasi sampel, pembuatan pereaksi sari kulit buah naga serta pengujian sampel secara kualitatif.

\section{METODE PENELITIAN}

Penelitian ini dilakukan di Laboratorium Kimia Farmasi Stikes Samarinnda dan Laboratorium Kimia Bahan Alam UMKT. Objek penelitian ini adalah pentol bakso yang akan diidentifikasi ada atau tidaknya boraks dengan pereaksi alami menggunakan sari kulit buah naga merah. Sampel menggunakan teknik pengambilan sampel dengan metode Purposive Sampling. Penelitian ini berjalan selama bulan Februari-Mei 2020. Alat yang digunakan pada penelitian ini adalah cawan porselin, corong gelas, gelas kimia, kertas saring, mortir dan stemper, spatel, pipet dan tabung reaksi. Bahan yang digunakan pada penelitian ini adalah sampel pentol bakso, sari kulit buah naga merah, boraks dan air suling.

\section{Prosedur Penelitian}

\section{a. Determinasi}

Determinasi Kulit Buah naga merah dilakukan untuk mengetahui kebenaran sampel. Determinasi dilakukan di labolatorium Fisiologi Tumbuhan Fakultas Matematika dan ilmu pengetahuan Alam (FMIPA) Universitas Mulawarman Samarinda.

\section{b. Pengumpulan sampel}

Pentol bakso yang dijadikan sampel yaitu Lima sampel pentol bakso yang didapatkan dari pedagang bakso di Jl. AW Sjahranie Kelurahan Air Hitam.

c. Pembuatan spike

Spike merupakan sampel pentol bakso yang sengaja ditambahkan 
boraks, yang berfungsi sebagai kontrol positif, dibuat dalam tiga konsentrasi sebagai berikut :

1. Spike dengan konsentrasi $10.000 \mathrm{mg} / \mathrm{kg}$ yang diberi kode A didapatkan dari sampel pentol bakso tanpa boraks (di buat sendiri oleh peneliti) sebanyak 24,75 gram ditambahkan dengan 0,25 gram boraks, dan selanjutnya dihaluskan dengan mortir.

2. Spike dengan konsentrasi $1000 \mathrm{mg} / \mathrm{kg}$ yang diberi kode B didapatkan dari spike A ditimbang sebanyak 22,5 gram, yang ditambahkan 2,5 gram pentol bakso tanpa boraks, dihaluskan dengan mortir.

3. Spike dengan konsentrasi 100 $\mathrm{mg} / \mathrm{kg}$ yang diberi kode $\mathrm{C}$ didapatkan dari spike $\mathrm{B}$ ditimbang sebanyak 22,5 gram, yang ditambahkan 2,5 gram pentol bakso tanpa boraks, dihaluskan dengan mortir.

\section{d. Preparasi sampel}

1. Masing-masing sampel pentol bakso ditimbang sebanyak 2,5 gram dan ditambah $10 \mathrm{ml}$ air suling.

2. Sampel dihaluskan dengan mortir, disaring dan diambil filtratnya.

3. Perlakuan yang sama seperti diatas diulang untuk spike A, B dan C.

e. Pembuatan

Pereaksi Sari

\section{Bahan Alami}

Buah naga dikupas, dibersihkan dan dipisahkan dari kulitnya kemudian kulitnya dicuci dan ditiriskan setelah itu kulit buah naga merah sebanyak 500 gram, dan ditambahkan air sebanyak $1000 \mathrm{ml}$ blender sampai tercampur rata (Niah et al., 2018)

\section{f. Proses Pembuatan $\mathrm{AgNO}_{3}$}

Timbang $\mathrm{AgNO}_{3}$ sebanyak $10 \mathrm{mg}$. Di masukkan kedalam beaker glass 100ml dan ditambahkan aquadest sebanyak 10ml. Aduk hingga larut sempurna. Menurut hasil penelitian Prayoga (2016) mengidentifikasi boraks dalam bakso menggunakan pereaksi $\mathrm{AgNO}_{3}$ di lakukan dengan cara fitrat sampel dimasukkan kedalam tabung reaksi, lalu ditambahkan larutan perak nitrat. Jika terbentuk endapan putih, maka bakso tersebut mengandung boraks.

\section{g. Pengujian sampel}

1. Larutan sampel sebanyak $2 \mathrm{ml}$ ditambahkan sari bahan alami kulit buah naga merah masingmasing sebanyak 5 tetes. Apabila sampel yang diuji mengandung boraks, sampel akan mengalami perubahan warna yaitu dari warna ungu kemerahan menjadi merah muda pucat.

2. Pengujian ini juga dilakukan terhadap spike sebagai kontrol positif dan sampel pentol bakso tanpa boraks sebagai kontrol negatif

\section{Analisis Data}

Analisis data yang digunakan dalam penelitian ini menggunakan 
metode analisa deskritif yaitu yang dilakukan untuk memperoleh gambaran secara objektif terhadap suatu penelitian.

\section{HASIL DAN PEMBAHASAN}

\section{a. Determinasi dan Hasil pengamatan boraks pada spike}

Hasil determinasi dari sampel kulit buah naga merah menunjukkan spesies Hylocereus undatus (Haw.) Britton \& Rose. Menurut hasil penelitian Simanjuntak (2014), kulit buah naga merah memiliki warna merah yang disebut antosianin. Antosianin merupakan pewarna yang paling penting dan paling banyak tersebar luas dalam tumbuhan. Pigmen ini termasuk dalam golongan senyawa flavanoid yang bertanggung jawab terhadap timbulnya warna oranye, jingga, merah ungu, dan biru pada beberapa daun, bunga dan buah. (Lestario,dkk 2011: Lestari dkk, 2019).

Tabel 1. Hasil pengamatan warna identifikasi pada pentol bakso (spike)

\begin{tabular}{ccc}
\hline No & Pereaksi & $\begin{array}{l}\text { Perubahan } \\
\text { Warna }\end{array}$ \\
\hline 1. & Kulit buah & Merah muda \\
naga merah & pucat \\
2. & $\mathrm{AgNO}_{3}$ & $\begin{array}{c}\text { Endapan putih } \\
\text { perak } \\
\end{array}$ \\
& & metaborat \\
\hline
\end{tabular}

\section{b. Hasil Identifikasi Boraks Pada sampel Pentol Bakso}

Hasil pengamatan yang diperoleh melalui reaksi warna menggunakan bahan alami dari ekstrak (sari) kulit buah naga merah menunjukkan hasil pengujian sebagai berikut:
1. Uji boraks dengan ekstrak (sari) kulit buah naga merah

Uji boraks dengan ekstrak (sari) kulit buah naga merah, yaitu dengan cara sampel ditetesi dengan sari kulit buah naga merah kemudian akan terjadi perubahan warna ungu kemerahan menjadi merah muda pucat. Hal ini dudasari oleh penelitian Simajuntak dkk (2014) yaitu antosianin pada buah naga bertanggung jawab terhadap reaksi dengan boraks.

Setelah dilakukan uji sampel dengan menggunakan larutan ekstrak (sari) kulit buah naga merah, kelima sampel tersebut yaitu sampel 1, 2, 3, 4, dan 5 menunjukkan tidak ada perubahan warna dari kelima sampel tersebut dan dari hasil pengujian menunjukkan bahwa sampel pentol bakso tidak ada yang mengandung boraks. Apabila Sampel yang diuji mengandung boraks, sampel akan mengalami perubahan warna yaitu dari ungu kemerahan berubah menjadi merah muda pucat. Hasil penelitian ini menunjukkan sampel bakso pada 5 pedagang di Kelurahan Air Hitam tidak menggunakan boraks. Hal ini tentunya menghindari konsumen mengkonsumsi boraks karena dapat membahayakan kesehatan.

2. Uji Boraks Dengan Menggunakan Larutan $\mathrm{AgNO}_{3}$

Identifikasi boraks pada sampel pentol bakso yang berjumlah lima sampel dari lima pedagang bakso yang dijual Kelurahan Air Hitam. Hasil pengujian warna dengan menggunakan pereaksi $\mathrm{AgNO}_{3}, \quad$ Hasil akan disimpulkan positif mengandung boraks, apabila sampel setelah 
ditambahkan dengan $\mathrm{AgNO}_{3}$ akan menghasilkan endapan putih Perak metaborat. Setelah dilakukan uji sampel dengan menggunakan larutan $\mathrm{AgNO}_{3}$, kelima sampel tidak menghasilkan endapan putih metaborat (hasil hegatif)

Tabel 2. Hasil Identifiksasi Boraks Pada Pentol Bakso

\begin{tabular}{ccc}
\hline Sampel & $\begin{array}{c}\text { Kulit } \\
\text { buah } \\
\text { Naga } \\
\text { merah }\end{array}$ & \\
\hline 1 & - & - \\
2 & - & - \\
3 & - & - \\
4 & - & - \\
5 & - & - \\
Spike A & + & + \\
Spike B & + & + \\
Spike C & + & + \\
\hline Kontrol negatif & - & - \\
\hline \multicolumn{2}{c}{ Menurut hasil penelitian dari }
\end{tabular}
(Wijaya, 2018) Identifikasi boraks pada pentol bakso yang dijual di Bumi Tamalanrea Permai (BTP) Kota Makassar setelah di tambahakan dengan larutan $\mathrm{AgNO}_{3}$ tidak ada endapan, hasil ini menunjukkan bahwa ke 7 sampel bakso negatif mengandung boraks. dan hasil penelitian dari Prayoga dkk (2016) identifikasi boraks dalam bakso yang di peroleh dari pedagang Kelurahan bahagia Bekasi setelah ditambahkan dengan larutan $\mathrm{AgNO}_{3}$ bahwa ada beberapa sampel yang mengandung boraks. Sampel yang mengandung boraks setelah diuji warna dengan $\mathrm{AgNO}_{3}$ akan menghasilkan endapan putih perak metaborat, $\mathrm{AgBO}_{2}$ dari larutan boraks yang cukup pekat, yang larut baik dalam larutan amonia encer maupun dalam asam asetat. Reaksi yang terjadi

$$
\begin{aligned}
& \mathrm{B}_{4} \mathrm{O}^{2}-+4 \mathrm{Ag}^{+}+\mathrm{H}_{2} \mathrm{O} \longrightarrow 4 \mathrm{AgBO}_{2} \downarrow+2 \mathrm{H}^{+} \\
& 2 \mathrm{AgBO}_{2} \downarrow+3 \mathrm{H}_{2} \mathrm{O} \rightarrow \mathrm{Ag}_{2} \mathrm{O} \downarrow+2 \mathrm{H}_{3} \mathrm{BO}_{3}
\end{aligned}
$$

Mengkonsumsi Boraks dalam kadar yang tinggi dalam makanan dan terserap dalam tubuh menimbulkan kerusakan pada usus, otak, atau ginjal. Asam boraks ini akan menyerang sistem saraf pusat dan menimbulkan gejala kerusakan seperti rasa mual, muntah, diare, kejang perut, iritasi kulit dan jaringan lemak, gangguan peredaran darah, kejang-kejang akibat koma, bahkan kematian dapat terjadi karena ada gangguan sistem sirkulasi darah (Nurul, 2017).

\section{SIMPULAN}

Hasil identifikasi boraks pentol bakso dalam penelitian ini yang diperoleh dari lima pedagang Bakso di Kelurahan Air Hitam dengan menggunakan pereaksi warna dari ekstrak (sari) kulit buah naga merah menunjukkan bahwa seluruh sampel pentol bakso semuanya memberikan hasil negatif.

\section{UCAPAN TERIMAKASIH}

Terimakasih kepada Universitas Muhammadiah Kalimantan Timur (UMKT) yang telah mendanai penelitian ini

\section{DAFTAR PUSTAKA}

Hartati, k., F. 2017. "Analisis Boraks Secara Cepat, Mudah Dan Murah Pada Kerupuk" Jurnal Teknologi Proses Dan Inovasi Industri, Vol 2, No (1): 33 
Indrati, R., dan Gardijo, M. 2013. Pendidikan Konsumsi Pangan Aspek Pengolahan dan Keamanan. Jakarta : PT. Fajar InterPratama Mandiri. Hal: 79

Khaira, K. 2016. "Pemeriksaan Formalin Pada Tahu Yang Beredar Di Pasar Batusan Sangkar Menggunakan Kalium Permanganat $\left(\mathrm{KmnO}_{4}\right)$ Dan Kulit Buah Naga". Jurnal Sains dan Teknologi, Jurusan Tarbiyah STAIN Batusangkar. Hal: 4-5

Lestari, A.L. dan Puspita, M.L. 2018. Kandungan Zat Gizi Makanan Khas Yogyakarta. Yogyakarta: UGM Press. Hal: 152.

Lestari, D, Kartika,R, Marlina, E, dan Syamsul, E.S, 2019, Analisis Fragmentasi GC-MS Senyawa Aktif Antikanker Leukimia Fraksi Kloroform Umbi Bawang Tiwai (Eleutherine bulbosa (Mill.) Urb),Jurnal Ilmiah Manuntung 5 (1), page 1-7.

Lestario, N.L. dan Rahyuni E., dan Timotius, H.K. 2011.” Kandungan Antosianin Dan Identifikasi Antosianin Dari Kulit Buah Jenitri (Elaeocarpus angustifolius Blume" Jurnal AGRITECH, Fakultas Sains dan Matematika, Universitas Kristen Satya Wacana. Vol 31, No (2): 93

Nurul, A. 2017. "Penyehatan Makanan Dan Minuman". Katalog Dalam
Terbitan (KDT). Yogyakarta: Hal: 111,115

Niah, R. Dan Baharsyah, R.K. 2018. "Uji aktivitas Antioksidan Ekstrak Etanol Kulit Buah Naga Merah Super (Hyclocereus costaricencies". Jurnal Pharmascience Vol 05(01):14-21

Prayoga, T. dan Mekasari, N. 2016. "Identifikasi Boraks Dalam Bakso Di Kelurahan Bahagia Bekasi Utara Jawa Barat Dengan Metode Analisis Kualitatif". Jurnal Akademi Farmasi IKIFA. Vol 01(01):113-120

Syamsul,E.S., Apriliana, A, Saleh, C, 2018. Thrombocyte Counts in Mice After the Administration of Chloroform Fraction of Eleutherine palmifolia L (Merr). Proceeding International Conference, Universitas Islam Indonesia, Departement of Pharmacy

Simanjuntak, dkk. 2014. "Ekstrak Pigmen Antosianin Dari Kulit Buah Naga merah (Hylocereus polyrhizus). Jurnal Teknik Kimia Universitas Sumatra Utara. Hal 2.

Wijaya, A. 2018. "Analisis Bahan Tambahan Pangan Berbahaya Pada Jajanan Di Bumi Tamalanrea Permai (BTP) Kota Makassar". Jurnal Ilmiah Kesehatan Diagnosis Vol 12, No (6): 